\title{
Heparin Intravena Terhadap Rasio PF pada Pasien Acute Lung Injury (ALI) dan Acute Respiratory Distress Syndrome (ARDS)
}

\author{
Aditya Kisara*, Mohamad Sofyan Harahap**, Uripno Budiono** \\ *Bagian Anestesiologi dan Terapi Intensif RS PKU Muhammadiyah Cepu \\ **Bagian Anestesiologi dan Terapi Intensif FK Undip/ RSUP Dr. Kariadi, Semarang
}

\section{ABSTRACT}

Background: Acute respiratory distress syndrome (ARDS) gained major medical attention with the availability of mechanical ventilation and establishment of intensive care units. ALI/ ARDS patient are associated with aggravate or initiate pulmonary inflammation and lung damage through fibrin deposition. Heparin may reduce pulmonary inflammation and fibrin deposition. We therefore assessed whether low dose intravenous heparin improved arterial PO2/FiO2 (PF ratio)

Objectives: To analize effect of low dose intravenous heparin on PF Ratio in ALI/ARDS patients with Mechanical Ventilation

Methods: Thirty patients expected to require mechanical ventilation for more than 48 hours were enrolled in a randomized trial divided into two groups $(n=15)$. Group 1 were gived heparin $10 \mathrm{iu} / \mathrm{kgbw} / \mathrm{hr}$ and group 2 as control. Mann-Whitney U test and post hoc test with LSD was performed to compare these groups.

Results: Intravenous heparin was not associated with a significant improvement $P F$ ratio in day $0(p=0,152)$, day $1 \quad(p=0,287)$ and day $2(p=0,879)$. The average daily of thrombocytes were not significant at both heparin group and control grup ( $p=0,216$ in day 0, $p=0,911$ in day 1 and $p=0,941$ in day 2).

Conclusions: Intravenous heparin with dose 10 unit/kgbw/hr in ALI/ARDS patients with mechanical ventilator was not associated with improvement of PF ratio. Further trials are required to confirm these findings.

Key word: ALI/ARDS, mechanical ventilator, intravenous heparin

\section{ABSTRAK}

Latar Belakang: Dengan adanya ICU dan penggunaan ventilator mekanik, ARDS menjadi salah satu perhatian di bidang medis. Pasien ALI/ ARDS berhubungan dengan reaksi inflamasi dalam paru-paru dan terjadinya deposit fibrin yang mengakibatkan kerusakan paru, salah satu tandanya adalah terjadi penurunan PF Ratio. Heparin mungkin dapat mengurangi proses inflamasi dan deposit fibrin dalam paru. Pada penelitian ini dilakukan penilaian apakah pemberian heparin intravena dosis rendah dapat meningkatkan nilai perbandingan PO2/FiO2 (PF ratio).

Tujuan: Untuk menilai pengaruh pemberian heparin intravena pada pasien ALI/ARDS dengan ventilator mekanik.

Metode: Tiga puluh pasien yang diperkirakan membutuhkan ventilator minimal dua hari dipilih secara acak dan di ikutkan dalam penelitian. Group pertama ( 15 pasien) diberi 
heparin 10 unit/kgbb/ jam dan group kedua sebagai kontrol. Untuk membandingkan rerata kedua group digunakan tes Mann-Whitney U dan dilakukan uji post hoc dengan LSD.

Hasil: Pemberian heparin intravena tidak menunjukkan peningkatan rasio PF secara bermakna baik pada hari $0(p=0,152)$, hari $1(p=0,287)$ atau hari $2(p=0,287)$. Jumlah rata-rata trombosit juga menunjukkan perbedaan yang tidak bermakna baik pada hari $0(p=0,216)$, hari $1(p=0,911)$ atau hari $2(p=0,941)$.

Simpulan: Pemberian heparin intavena dengan dosis 10 unit/kgbb/ jam pada pasien ALI/ARDS dengan ventilator mekanik menghasilkan rasio PF yang berbeda tidak bermakna dengan kelompok kontrol. Penelitian lebih lanjut diperlukan untuk mengkonfirmasi hasil penelitian ini.

Kata kunci: ALI/ARDS, ventilator mekanik, heparin intravena

\section{PENDAHULUAN}

Acute lung injury (ALI)/ Acute respiratory disstres syndrome (ARDS) merupakan penyakit yang mengancam jiwa pada pasien critical ill di ICU. Kedua hal tersebut merupakan respon inflamasi akibat adanya kelainan baik langsung atau tidak langsung pada paru. Menurut penelitian, angka kejadian acute lung injury (ALI)/ acute respiratory disstress syndrome (ARDS) sekitar 32- 34 kasus per 100.000 penduduk. Angka kematian pasien ARDS di ICU mencapai 34\%, hanya $32 \%$ yang berhasil survive dan pulang ke rumah. Perkiraan dari insiden ALI/ ARDS tidak mudah karena adanya keterbatasan metodologi penelitian dan sistem pengkodean penyakit yang tidak akurat. Banyaknya kesulitan ini menyebabkan penelitian untuk mendeskripsikan penyakit ini mempunyai hasil yang berbeda- beda. Perhatian besar ditujukan untuk pengelolaan pasien dengan ALI/ARDS di ICU. Berbagai macam terapi ditujukan untuk mengurangi angka morbiditas dan mortalitas pasien di ICU. ${ }^{1,2}$ Pada pasien dengan ALI/ARDS terjadi proses inflamasi jaringan paruparu. Hal ini disebabkan berbagai macam faktor yang akan menyebabkan paru-paru kehilangan fungsinya. Alveoli kehilangan kemampuannya dalam pertukaran oksigen dan karbondioksida. Hal ini disebabkan karena saccus alveoli kolaps atau edema. Kondisi ini biasanya berlanjut dan membutuhkan pemakaian ventilator mekanik bagi pasien. Pemakaian ventilator mekanik akan menyebabkan meningkatnya produksi mediator- mediator inflamasi seperti 
plasminogen activator inhibitor-1 (PAI1), transforming growth factor- $\beta 1$ (TGF - 1 1), dan murine macrophage inflammatory protein-2 (MIP-2), apoptosis dari sel saluran napas, neutrophil influx, dan kebocoran kapiler. Menurut penelitian terdahulu, heparin mempunyai efek sebagai anti koagulan dan anti inflamasi. Pada penelitian tersebut heparin diberikan dengan cara inhalasi dan intravena. Heparin juga digunakan sebagai profilaksis trombosis pada pasien yang memiliki resiko terjadi trombosis vena dalam. $^{1-8}$

Acute respiratory syndrome (ARDS), juga dikenal sebagai Respiratory Disstress syndrome atau Acute Respiratory Disstress syndrome merupakan reaksi serius terhadap berbagai bentuk cedera pada paru-paru. ARDS adalah penyakit paru-paru yang disebabkan oleh masalah baik langsung maupun tidak langsung. Hal ini ditandai adanya peradangan pada parenkim paru yang menyebabkan gangguan pertukaran gas, keluarnya mediator inflamasi, hipoksemia dan sering menyebabkan multiple organ failure. ${ }^{1-8}$ ARDS/ALI merupakan suatu respons terhadap berbagai macam kerusakan atau penyakit yang mengenai paru-paru baik itu secara langsung atau tidak langsung.

Penyebab langsung antara lain: aspirasi asam lambung, tenggelam, kontusio paru, pnemonia berat, emboli lemak, emboli cairan amnion, inhalasi bahan kimia, keracunan oksigen. Penyebab tidak langsung terdiri dari: sepsis, trauma berat, syok hipovolemik, transfusi darah berulang, luka bakar, pankreatitis, koagulasi intravaskular diseminata dan anafilaksis. ${ }^{2,5,6,8,9}$

Ada 3 fase dalam patogenesis ARDS yaitu fase eksudatif, fase permulaan, dengan cedera pada endothelium dan epitelium, inflamasi, dan eksudasi cairan, terjadi 2-4 hari sejak serangan akut, fase proliferasi, terjadi setelah fase eksudatif, ditandai dengan influks dan proliferasi fibroblast, sel tipe II dan miofibroblast, menyebabkan penebalan dinding alveolus dan perubahan eksudat perdarahan menjadi jaringan granulasi seluler / membran hyalin. Fase proliferasi merupakan fase menentukan yaitu cedera bisa sembuh atau menjadi menetap. Ada resiko terjadi pneumothorak; dan fase fibrosis atau recovery, jika pasien bertahan sampai 3 minggu, paru akan mengalami remodeling dan fibrosis. 
Fungsi paru berangsur membaik dalam waktu 6 - 12 bulan, dan sangat bervariasi antar individu, tergantung keparahan cederanya. Kondisi yang lebih baik dari ARDS disebut Acute lung injury (ALI). Untuk membedakannya perlu dilakukan pemeriksaan analisa gas darah arteri, dimana bila rasio $\mathrm{PF}<200$ disebut ARDS dan bila rasio $\mathrm{PF}<300$ disebut ALI. ${ }^{9.10}$

Berdasarkan hal- hal diatas peneliti ingin mengetahui manfaat heparin dengan dosis tromboprofilaksis terhadap pasien ALI/ARDS, dengan cara mengukur rasio $\mathrm{PF}$ pada pasien ALI/ ARDS dengan ventilator mekanik.

\section{METODE}

Penelitian ini merupakan penelitian klinis eksperimental yang dilakukan secara acak, sejak Mei 2012 sampai dengan September 2012. Sampel diambil dari pasien ICU/HCU RSUP Dr. Kariadi Semarang yang memenuhi kriteria inklusi dan eksklusi, menggunakan random sampling dibagi menjadi dua kelompok yaitu kelompok pertama diberi heparin intravena dan kelompok kedua sebagai kontrol, tempat pemeriksaan laboratorium di Laboratorium Patologi Klinik RSUP Dr.
Kariadi Semarang. Dari perhitungan, jumlah sampel yang diperlukan adalah 15 orang. Kriteria inklusi meliputi: usia 12-70 tahun, didiagnosis ALI/ARDS dan menggunakan ventilator. Kriteria eksklusi berupa syok perdarahan.

Seleksi penderita dilakukan pada saat masuk ICU, penderita yang memenuhi kriteria ditentukan sebagai sampel. Penelitian dilakukan terhadap 30 penderita. Semua pasien diperiksa laboratorium lengkap pada waktu masuk ICU. Sampel dibagi menjadi dua kelompok, kelompok diberikan heparin intravena 10 unit/kgbb/jam 50 dan kelompok tanpa heparin. Pemberian heparin intravena dilakukan dengan Syring Pump (SP) dengan spuit $20 \mathrm{cc}$ dengan diencerkan menggunakan Nacl $0,9 \%$. Ventilator disetting berdasarkan pedoman ARDS net. Hari nol, satu dan dua dilakukan pemeriksaan kembali kadar, PTT dan BGA. Hasil pemeriksaan dibandingkan dengan data dasar. Setelah itu dilakukan analisis statistik. Monitoring pada umumnya dengan mengukur tensi, nadi, laju pernafasan, suhu, $\mathrm{SpO}_{2}$ dan adanya perdarahan medis. Timbulnya perdarahan medis pada pasien, akan dikeluarkan dari penelitian. 
Semua perhitungan menggunakan software SPSS (Statistical Package for Social Science) versi 15.0. Data yang dikumpulkan mencakup karakteristik umum sampel (umur, tinggi badan, berat badan APACHE skor, nilai PTT dan BGA sebelum dan sesudah perlakuan. Data yang terkumpul kemudian di-coding, di-entry ke dalam komputer dan setelah itu dilakukan cleaning data. Data deskriptif disimpulkan dalam mean $\pm \mathrm{SD}$, median (minimum-maksimum) atau presentase. Selanjutnya, dilakukan analisis deskriptif dengan menghitung proporsi gambaran karakteristik responden menurut kelompok perlakuan.

Hasil analisis disajikan dalam bentuk tabel terbuka. Selanjutnya, dilakukan uji normalitas data dan analisis dinferensial untuk menguji hipotesis dengan menggunakan Kolmogorov Smirnov dan hasil rerata antar kelompok dibandingkan menggunakan One Way Anova test. Kemudian dilakukan analisa uji post hoc dengan menggunakan LSD.

Sebelum dilakukan penelitian, informed consent tertulis dimintakan kepada keluarga pasien dengan penjelasan secara lisan tentang tujuan dan manfaat.

\section{HASIL}

Pada penelitian ini sebanyak 30 pasien ALI/ ARDS yang diperkirakan memakai ventilator selama minimal dua hari dan masuk kriteria inklusi diikutkan dalam sampel penelitian. Pasien dikelompokkan secara acak dalam kelompok yang mendapat heparin intravena dan yang tidak mendapatkan heparin .

Pada Tabel 1 diperlihatkan data dasar seluruh subjek. Rerata umur kelompok heparin adalah 50 tahun $\pm 17,75$ sedikit lebih tua dibandingkan kelompok kontrol yaitu 44 tahun $\pm 16,33$. Rerata berat badan kelompok heparin 54,33 $\mathrm{kg}( \pm$ 7,28), untuk kelompok kontrol 56,07 ( \pm $9,11)$ sedangkan rerata tinggi badan kelompok heparin 163,67 cm $( \pm 5,01)$, kelompok kontrol 161,73 cm $( \pm 5,42)$. Rerata nilai apache kelompok heparin $19,53( \pm 5,12)$, kelompok kontrol 18,2 $( \pm 4,86)$. Dari data tersebut rerata umur, berat badan, tinggi badan dan skor APACHE antara kelompok heparin dan kontrol didapatkan hasil berbeda tidak bermakna ( $\mathrm{p}>0,05)$. Dengan Uji normalitas dengan Kolmogorov Smirnov didapatkan distribusi yang normal antara kedua kelompok.

Rerata PTT hari 1 kelompok heparin 
Tabel 1. Karakter Subjek Penelitian

\begin{tabular}{lcll}
\hline Parameter & Kontrol & \multicolumn{1}{c}{ Heparin } & \multicolumn{1}{c}{$\mathrm{P}$} \\
\hline Jenis Kelamin & $5: 10$ & $9: 6$ & 0,153 \\
Umur & $44,33 \pm 16,33$ & $50,67 \pm 17,75$ & 0,318 \\
Berat Badan & $56,07 \pm 9,11$ & $54,33 \pm 7,28$ & 0,569 \\
Tinggi Badan & $161,73 \pm 5,42$ & $163,67 \pm 5,01$ & 0,272 \\
Apache & $18,2 \pm 4,86$ & $19,53 \pm 5,12$ & 0,471 \\
\hline
\end{tabular}

Tabel 2. Parameter PTT

\begin{tabular}{rrrr}
\hline Parameter & Kontrol & Heparin & $\mathrm{p}^{*}$ \\
\hline PTTharike 0 & $33,68 \pm 5,64$ & $33,85 \pm 3,47$ & 0,611 \\
PTTharike 1 & $31,83 \pm 2,08$ & $45,13 \pm 31,02$ & 0,017 \\
PTTharike 2 & $31,97 \pm 0,79$ & $40,96 \pm 18,07$ & 0,007 \\
\hline
\end{tabular}

*bermakna apabila $\mathrm{p}<0,05$

Tabel 3. Perbedaan Rerata Rasio PF Antar Kelompok

\begin{tabular}{llcl}
\hline \multicolumn{1}{c}{ Parameter } & Kontrol & Heparin & $\mathrm{p}^{*}$ \\
\hline Rasio PF : & & & \\
Harike 0 & $254,7 \pm 61,46$ & $219,06 \pm 68,86$ & 0,152 \\
Harike 1 & $282,2 \pm 39,08$ & $262,55 \pm 57,91$ & 0,287 \\
Harike 2 & $289,3 \pm 75,06$ & $285,00 \pm 82,59$ & 0,879 \\
\hline p** & 0,252 & 0,043 &
\end{tabular}

* perbandingan antar kelompok (bermakna bila $\mathrm{p}<0,05)$

** perbandingan dalam kelomp ok (b ermakna bila $\mathrm{p}<0,05$ ) 


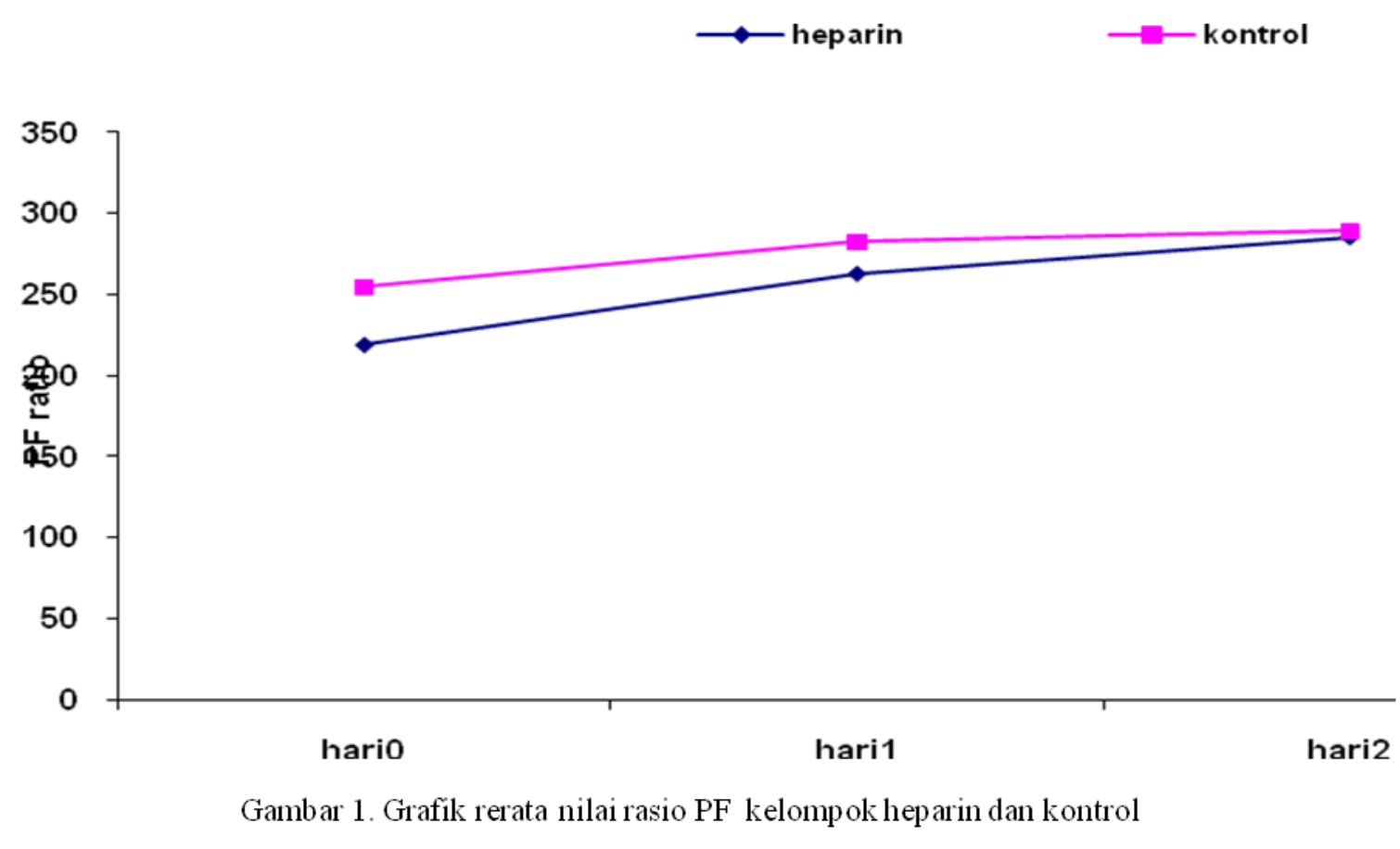

kontrol

adalah $45,13( \pm 31,02)$, untuk hari 2 adalah 40,96 $( \pm 18,07)$ dibandingkan kelompok kontrol nilai PTT hari 1 adalah 31,83 $( \pm 2,08)$ untuk hari 2 adalah $31,97( \pm 0,79)$. Pemeriksaan PPT dilakukan tiap hari untuk melihat efek sistemik pemberian heparin. Nilai PTT kelompok heparin memanjang pada hari pertama dan kedua secara statistik bermakna $(p<0,05)$. Secara lengkap dapat dilihat pada Tabel 2.

Rerata rasio PF hari 1 kelompok heparin adalah 262,55 $( \pm 57,91)$, untuk hari 2 adalah 285,00 $( \pm 82,59)$ dibandingkan kelompok kontrol rasio PF hari 1 adalah 282,2 $( \pm 39,08)$ untuk hari 2 adalah $289,3 \pm 75,06$. Data parameter rasio PF pada kelompok non heparin dan kelompok heparin diuji normalitasnya menggunakan Shapiro- Wilk dan didapatkan distribusi tidak normal $(\mathrm{p}<0,05)$. Data yang di dapat kemudian diuji perbedaan reratanya dengan uji parametrik dengan One Way Anova. Pada hasil didapatkan perbedaan nilai rasio PF yang tidak bermakna antara kelompok heparin dan kontrol baik pada hari ke $0(\mathrm{p}=0,152)$, hari $1(\mathrm{p}=0,287)$, dan hari $2(p=0,87)$. Pada kelompok heparin terjadi perubahan nilai rasio $\mathrm{PF}$ yang bermakna antara hari ke 0 sampai hari ke $2(p=0,043)$. Secara lengkap dapat dilihat pada Tabel 3.

Dari grafik pada Gambar 1 tampak bahwa pada kelompok heparin terjadi perubahan nilai rasio PF yang bermakna antara hari ke 0 sampai hari ke 2 dengan nilai $\mathrm{p}=0,043$. 


\section{PEMBAHASAN}

Untuk uji karakteristik kelompok penelitian, yaitu umur, berat badan, tinggi badan, setelah dilakukan uji beda antara kedua kelompok, tidak didapatkan adanya perbedaan yang bermakna diantara dua kelompok penelitian sehingga kedua kelompok tersebut layak untuk dibandingkan.

Data parameter rasio PF pada kelompok non heparin dan kelompok heparin diuji normalitasnya menggunakan Kolmogorov Smirnov dan didapatkan distribusi tidak normal $(\mathrm{p}<0,05)$. Data yang di dapat kemudian diuji perbedaan reratanya dengan uji parametrik dengan One Way Anova. Pada kedua kelompok kemudian dilakukan uji post hoc dengan LSD, hasil bermakna pada perbedaan nilai rasio PF pada kelompok heparin hari 0 dan 1 dan perbedaan nilai rasio PF pada kelompok heparin hari 0 dan 2. Sedangkan perbedaan nilai rasio PF pada kelompok kontrol hari 0 dan 1dan perbedaan nilai rasio PF pada kelompok kontrol hari 0 dan 2 tidak signifikan

Pada penelitian ini tidak ditemukan perbedaan yang bermakna terhadap nilai PF ratio antara kelompok heparin dan non heparin baik pada hari 0 , hari 1 dan hari $2(\mathrm{p}>0,05)$. Hal ini mungkin dikarenakan pemberian heparin dengan dosis 10 unit/kgbb/jam belum cukup memberikan efek terhadap sistem koagulasi. Walaupun pada penelitian ini didapatkan kenaikan nilai PTT yang cukup bermakna secara statistika, namun tidak mencapai target terapi profilaksis sebesar 1,5 - 2,5 kali kontrol. Hal ini menyebabkan kemungkinan untuk terjadinya mikrotrombus di alveoli masih sangat besar. Dosis yang digunakan berdasarkan penelitian sebelumnya yang merupakan dosis heparin untuk profilaksis trombo emboli. $^{11}$

Pada penelitian oleh Dixon dkk, dikatakan bahwa pemberian heparin intravena pada pasien dengan penyakit radang paru akut pada pasien bedah jantung mengakibatkan penurunan angka kejadian trombosis pada mikrovaskular paru. Penelitian pada binatang dengan ALI juga menunjukan berkurangnya mikro emboli dan penurunan formasi membran hyalin di vaskuler. Pada penelitian di atas juga dilakukan pemeriksaan terhadap sel-sel radang di paru untuk mengetahui fungsi heparin sebagai anti radang. Pada penelitian tersebut menggunakan dosis yang lebih besar dengan target ACT $>250$ detik. ${ }^{12,13}$ 
Jangka waktu penelitian yang singkat ( 2 hari) juga menjadi keterbatasan pada penelitian ini. Dua hari penelitian dimaksudkan untuk mengurangi faktor perancu lain yaitu timbulnya ventilator associated pneumonia. Tapi mungkin waktu tersebut terlalu pendek untuk mengetahui pengaruh heparin dikarenakan pada hari 2- 4 masih terjadi fase eksudatif. Terjadinya edema ini akan menghalangi pertukaran gas di alveoli. Lebih jauh lagi, edema dan berkurangnya surfaktan akan menyebabkan alveoli kolaps.

Walaupun didapatkan nilai PF ratio yang berbeda tidak bermakna, pada kelompok heparin menunjukan peningkatan pada hari 1 dan 2 . Hal ini menunjukkan adanya kecenderungan ke arah perbaikan. Penelitian yang dilakukan oleh Dixon menunjukan tidak ada perbedaan yang bermakna pada nilai rata-rata volume tidal, $P E E P$ dan respiratory rate, walaupun lama pemakaian ventilator pada pasien yang diberi heparin berbeda secara signifikan. Pasien yang diberi heparin menunjukkan waktu pemakaian ventilator yang lebih singkat dibanding yang tidak diberi heparin. Penelitian lain oleh Cox dkk, menunjukkan adanya peningkatan oksigenasi pada tikus yang diberi heparin. Tidak diikutinya perkembangan pasien lebih lama juga merupakan keterbatasan penelitian ini.

PF ratio sendiri bukan satu-satunya parameter untuk mengetahui manfaat heparin terhadap fungsi paru-paru. Masih banyak parameter lain yang perlu diteliti misalnya: pemeriksaan jumlah sel- sel radang paru dan perubahan seting ventilator karena data dari perubahan seting ventilator dapat diasumsikan merupakan efek perbaikan dari pemberian heparin. Dukungan data dari penelitian- penelitian selanjutnya akan lebih menyempurnakan penggunaan heparin untuk memperbaiki kondisi pasien dengan ALI/ARDS sehingga pemakaian heparin sebagai alternatif terapi pada pasien ALI/ARDS masih dapat dipertimbangkan.

\section{SIMPULAN}

Pemberian heparin intra vena dengan dosis 10 unit/kgbb/ jam pada pasien ALI/ ARDS dengan ventilator mekanik menghasilkan rasio PF yang berbeda tidak bermakna dengan kelompok kontrol, baik pada hari 0, 1 dan 2 .

Dari hasil penelitian ini disarankan dilakukan penelitian lebih lanjut menggunakan dosis heparin 
tromboprofilaksis pada pasien ALI/

ARDS dengan target PTT 1,5- 2,5 kali

kontrol dan waktu yang lebih lama

untuk mendapatkan efek lebih nyata pada rasio $\mathrm{PF}$.

\section{DAFTAR PUSTAKA}

1. Griffith J, Focus on definition and associations of ALI/ARDS.[homepage on internet].c2007[cited 2012 Jan 2] available from: http://www.frca.co.uk/article.aspx? articleid $=100811$

2. Raghavendran K, Napolitano L, Definition of ALI/ARDS.[homepage on internet].c2011 [cited 2012 Jan 2]avalaible from: http:// www.mendeley.com/research/definitionaliards/

3. Liu KD, Matthay MA, Advanced in Critical care for nephrologist: ALI/ARDS.[homepage on internet].c2008[cited 2012 Jan 4]avalaible from: http://cjasn.asnjournals.org/ content $/ 3 / 2 / 578$.short

4. Bellingan GJ, The pulmonary phisician in critical care: the phatogenesis of ALI/ARDS. [homepage on internet].c2002[cited 2012 Jan 2]available from: http://thorax.bmj.com/ content/57/6/540.full

5. Miller RD, Ericcson L, et.al. Anesthesia for thoracic Surgery. In :Miller's anaesthesia. $7^{\text {th }}$ ed, New York ,2011.

6. Morgan GE, Mikhail MS, Murray MJ, Anaesthesia for thoracotomy. In: Clinical anesthesiology. $4^{\text {th }}$ ed. New York: Mc GrawHill companies, 2006

7. Napolitano LM, ALI/ARDS Challenge and advanced, an issue of critical care. In The C 1 i n i c : I n t e $\mathrm{r} n$ a 1 Medicine,Saunders,2011;p.352

8. Agneli G, Prevention of venous thrombo embolism in surgical patient. [homepage on internet].c2004[cited 2012 Jan 2] avalaible from: http://circ.ahajournals.org/ content/110/24_suppl_1/IV-4.full

9. Huang $\mathrm{CC}$ et al, Unfraction heparin and enoxparin reduce high_stretch ventilation augmented lung injury: a prosctive, controled animal experiment.[homepage on internet].c2008[cited 2012 Jan 2] available from:http://creativecommon.org/license/by

10.Martin GS, Nebulized Heparin in Mechanically Ventilated Patient. [homepage on internet].c2008[cited 2012 Jan 2] available from:http://www.medscape.corn/viewarticle/

11. Agneli G, Prevention of venous thrombo embolism in surgical patient. [homepage on internet].c2004[cited 2012 Jan 2] avalaible from: http://circ.ahajournals.org/ content/110/24_suppl_1/IV-4.full

12.Huang CC, Unfraction heparin and enoxparin reduce high_stretch ventilation augmented lung injury: a prosctive, controled animal experiment.[homepage on internet].c 2008 [cited 2012 Jan 2] available from : http : // creative common .org / license/by

13. Martin GS, Nebulized Heparin in Mechanically Ventilated Patient. [homepage on internet] .c2008 [cited 2012 Jan 2] available from : http://www.medscape.corn/ viewarticle/ 